\title{
Production and Characterization of Thermoalkaliphilic Xylanase from Bacillus halodurans CM1, and Its Application on Degumming Process of Ramie (Boehmeria nivea L.Gaud) Fiber as Textile Raw Material
}

\author{
DEWI NANDYAWATI ${ }^{1,2}$, DEA INDRIANI ASTUTI ${ }^{1}$, NIKNIK NURHAYATI $^{2 *}$, ASEP RISWOKO $^{2}$, \\ AND IS HELIANTI ${ }^{2}$
}

\begin{abstract}
${ }^{I}$ Biotechnology Major, Graduate School, Institut Teknologi Bandung, Jalan Ganesha 10 Bandung, Indonesia; ${ }^{2}$ Center for Bioindustrial Technology, Laboratory for the Development of Agroindustrial and Biomedical Technology, National Agency for Research and Innovation, Gedung 611, Kawasan PUSPIPTEK Serpong, Tangerang Selatan,
\end{abstract}

Indonesia.

Ramie fiber is a potential raw material to substitute imported raw materials such as cotton. Due to its higher hemicellulose content, ramie fiber required hydrolysis in a process called degumming. Enzymatic degumming is environmentally friendly compared to traditional process which using chemicals. Alkaline thermostable xylanase has high ability in hemicellulose hydrolysis. The production of the CM1 xylanase was conducted by submerged fermentation of Bacillus halodurans CM1 in a 20 L bioreactor using Mamo and corncob medium under optimum conditions of temperature of $50^{\circ} \mathrm{C}, \mathrm{pH} 9$, agitation of $150 \mathrm{rpm}$, and aeration of $1 \mathrm{vvm}$. The fermentation yielded maximum CM1 xylanase activity of $641.6 \mathrm{U} \mathrm{mL}^{-1}$ or $475.41 \mathrm{U} \mathrm{mg}^{-1}$ after $30 \mathrm{~h}$. CM1 xylanase was stable at $50^{\circ} \mathrm{C}$, pH 9 for more than $2 \mathrm{~h}$, and relatively stable against $\mathrm{K}^{+}, \mathrm{Na}^{2+}, \mathrm{Co}^{2+}$ and $\mathrm{Ca}^{2+}$ metal ions, and Triton-X, SB Chem 9201 and Tween-80 surfactants. Degumming process was carried out by immersing ramie fibers in formulated degumming solution with rami to solution ratio of $1: 20$ at $50{ }^{\circ} \mathrm{C}$, with agitation of $150 \mathrm{rpm}$ for $3 \mathrm{~h}$.. The highest weight loss of rami fiber of $7.72 \%$ was reached by chemical - enzymatically degumming process. The highest tensile strength of $27.51 \mathrm{~g} \mathrm{Tex}^{-1}$ was reached by enzymatically degummed fiber that retained more than $90 \%$ of the control fiber (29.62 $\mathrm{g} \mathrm{Tex}^{-1}$ ). Degumming effect on whiteness index and fiber surface was also observed in this study.

Key words: alkaline thermostable xylanase, Bacillus halodurans CM1, enzymatic degumming, ramie fiber, textile industry

Serat rami merupakan bahan baku potensial untuk menggantikan bahan baku impor seperti kapas. Karena kandungan hemiselulosa yang tinggi, serat rami perlu dihidrolisis dengan proses degumming. Degumming enzimatis lebih ramah lingkungan dibandingkan proses tradisional menggunakan bahan kimia. Xilanase alkalitermofilik memiliki kemampuan dalam hidrolisis hemiselulosa. Produksi xilanase dilakukan dengan fermentasi submerged oleh Bacillus halodurans CM1 dalam bioreaktor 20 L menggunakan media Mamo dan tongkol jagung pada kondisi optimum suhu $50^{\circ} \mathrm{C}, \mathrm{pH}$ 9, $150 \mathrm{RPM}$ dan $1 \mathrm{vvm}$. Aktivitas spesifik optimum xilanase diukur dengan metode Bailey pada suhu $70^{\circ} \mathrm{C}$ dan $\mathrm{pH} 9$ adalah $475,41 \mathrm{U} / \mathrm{mg}$. Xilanase stabil pada suhu $50{ }^{\circ} \mathrm{C}, \mathrm{pH} 9$ dan relatif stabil terhadap ion logam $\mathrm{K}^{+}, \mathrm{Na}^{2+}, \mathrm{Co}^{2+}$ dan $\mathrm{Ca}^{2+}$ dan surfaktan Triton-X, SB Chem 9201 dan Tween-80. Proses degumming dilakukan dengan merendam serat rami dalam larutan degumming terformulasi dengan vlot 1:20 pada suhu $50^{\circ} \mathrm{C}, 150 \mathrm{rpm}$ selama 3 jam. Proses degumming enzimatik dapat menggantikan atau mengurangi penggunaan bahan kimia karena efeknya yang signifikan terhadap kualitas serat rami. Proses degumming enzimatis dan kimia mengurangi berat serat rami sebesar 7,72\%. Degumming enzimatis mempertahankan kekuatan tarik lebih dari 90\% dibandingkan perlakuan kontrol $\left(29.62 \mathrm{~g} \mathrm{Tex}^{-1}\right)$ yaitu sebesar 27,51 $\mathrm{g} \mathrm{Tex}^{-1}$. Pengaruh proses degumming pada derajat putih dan permukaan serat juga diamati dalam penelitian ini.

Kata kunci: Bacillus halodurans CM1, degumming enzimatis, industri tekstil, serat rami, xilanase alkalitermofilik

The application of industrial biotechnology, known as white biotechnology, uses biocatalyst to substitute the use of chemical catalyst in industrial process (Heux et al. 2015), improve end-product quality and environmentally friendly (Battan et al. 2015). Commonly used enzymes in textile processing are

*Corresponding author: Phone/Fax: +62-21-7560694; E-mail: niknik.nurhayati@bppt.go.id hydrolases and oxidoreductase for application in degumming, desizing and bleaching (removing impurities from cellulose fibers), finishing (removing fiber surface) and stoning (producing faded denim material). One of the important microorganism-based hydrolase enzymes in industry is xylanase. Xylanase is having the ability to degrade hemicellulose containing glucose polymer of xylan into xylooligosaccharide and D-xylose (Abd el aty et al. 2018). The application of 
xylanase in various industrial sectors such as pulp and paper, food, textiles, biofuels, animal feed is currently increasing due to its ability to reduce the use of hazardous chemicals in the process (Kumar et al. 2017). In textile industry, xylanase have been used for degumming process to remove gum or non-cellulosic impurities of natural fibers such as jute, flax and ramie. Ramie is one of potential natural bast fiber which have higher fiber strength and moisture regain compared to cotton fiber. Therefore, ramie is potential substitution to reduce the dependence on imported cotton (Novarini and Sukardan 2015). Decorticated ramie fiber consists of $68-76 \%$ cellulose, $13-14 \%$ hemicellulose, $1.9-2.1 \%$ pectin and $0.6-2 \%$ lignin (Lee et al. 2019). Noncellulosic impurities, called gum, should be removed from ramie fibers in order to improve spinning ability and meet the requirements of textile raw material (Cheng et al. 2020). Traditional degumming process commonly used alkali solution such as sodium hydroxide, sodium carbonate and others (Madhu and Chakraborty 2017). According to Meng et al. (2018) ramie fibers consist of $74.25 \%$ cellulose, $13.8 \%$ hemicellulose, $5.16 \%$ pectin and $1.3 \%$ lignin, while Ding et al. (2014) stated that it consists of $69.83 \%$ cellulose, $13.22 \%$ hemicellulose, $5.42 \%$ pectin and $1.84 \%$ lignin.

Xylanase is an effective enzyme for xylan depolymeration by breaking it down into small molecular weight oligomers, thereby increasing the absorption strength, whiteness and brightness of textile fibers (Kaur et al. 2016). In the previous study a thermophilic Bacillus halodurans CM1 has been isolated and partially characterized to have an alkaline thermostable xylanolytic activity (Ulfah et al. 2011). The objectives of this study were to produce and characterize the alkaline thermostablexylanase from Bacillus halodurans CM1 to be applied in degumming process of ramie fiber. Analyses of ramie fiber was also conducted in order to obtain effective degumming procedure.

\section{MATERIALS AND METHODS}

Bacterial Strains and Medium. The strain used in this study was Bacillus halodurans CM1 came from BPPT Culture Collection. Bacillus halodurans CM1 is a gram-positive bacteria isolated by Ulfah et al (2011) from Cimanggu hot springs, West Java. Seed culture media was a modified Horikoshi media (Kumar and Satyanarayana, 2011) contained $1 \% \mathrm{w} / \mathrm{v}$ peptone, 0.5 $\% \mathrm{w} / \mathrm{v}$ yeast extract, $0.1 \% \mathrm{w} / \mathrm{v} \mathrm{KH}_{2} \mathrm{PO}_{4}, 0.5 \% \mathrm{w} / \mathrm{v}$
$\mathrm{Na}_{2} \mathrm{CO}_{3}$, distilled water. Production media was Mamo media with a slight modification (Wibowo et al,2016) contained $5 \% \mathrm{w} / \mathrm{v}$ corncob, $0.5 \% \mathrm{w} / \mathrm{v}$ yeast extract, $0.1 \% \mathrm{w} / \mathrm{v} \mathrm{KH}_{2} \mathrm{PO}_{4}, 0.5 \% \mathrm{w} / \mathrm{v} \mathrm{Na} \mathrm{NO}_{3}, 0.2 \% \mathrm{w} / \mathrm{v}$ $\mathrm{NaCl}, 0.1 \% \mathrm{w} / \mathrm{v} \mathrm{MgSO}_{4}, 0.01 \% \mathrm{w} / \mathrm{v} \mathrm{CaCl}_{2}$, distilled water.

Chemicals and Rami Fiber. Chemicals used in this study were $0.5 \% \mathrm{w} / \mathrm{v}$ xylan beechwood, $2 \mathrm{mg} / \mathrm{ml}$ xylose, $50 \mathrm{mM}$ pH 9 Tris-Cl buffer, DNS reagent contained of $1 \% \mathrm{w} / \mathrm{v}$ dinitrosalicylic acid, $0.2 \% \mathrm{w} / \mathrm{v}$ phenol, $0.05 \% \mathrm{w} / \mathrm{v}$ sodium sulfite, and $1 \% \mathrm{w} / \mathrm{v}$ sodium hydroxide and $20 \% \mathrm{w} / \mathrm{v}$ potassium sodium tartrate, Biorad protein assay, and Bovine Serum Albumin for enzyme and protein assay. Metal ions used in this study were $\mathrm{K}^{+}, \mathrm{Na}^{+}, \mathrm{Ca}^{2+}, \mathrm{Co}^{2+}, \mathrm{Cu}^{2+}, \mathrm{Mn}^{2+}, \mathrm{Mg}^{2+}, \mathrm{Zn}^{2+}, \mathrm{Ni}^{2+}$, $\mathrm{Fe}^{3+}$ while surfactants used were SDS, Triton-X, Tween-80, Tween-20, EDTA, Teepol and SB Chem 9201 purchased from PT. Sadya Balawan, Bogor, West Java, Indonesia. Decorticated ramie fibers were purchased from CV. Rabersa, Wonosobo, Central Java, Indonesia.

Inoculum and Starter Culture Preparation. Inoculum was prepared by inoculating one bacterial colony of $B$. halodurans $\mathrm{CM} 1$ into $20 \mathrm{ml}$ seed culture media followed by incubation at $50^{\circ} \mathrm{C}, \mathrm{pH} 9,150 \mathrm{rpm}$ until $\mathrm{OD}_{600 \mathrm{~nm}}$ was $0,8-0,9$. Starter culture of Bacillus halodurans CM1 was produced by scaling up the volume of seed culture gradually by inoculating $10 \%$ volume of the inoculum having $\mathrm{OD}_{600} \mathrm{~nm}$ of $0.8-0.9$ into seed media starting from $150 \mathrm{~mL}$ up to $1500 \mathrm{~mL}$ under the same incubation condition previously described.

Production of The CM1 xylanase in $20 \mathrm{~L}$ Bioreactor. The CM1 xylanase was produced under submerged fermentation of $10 \mathrm{~L}$ modified Mamo media inoculated by $10 \%$ volume of the bacterial starter at initial concentration of $1 \times 10^{7}$ cells mL $\mathrm{mL}^{-1}$ in a $20 \mathrm{~L}$ bioreactor (Bailun bio 86-21-67867376). The fermentation was conducted at operational condition of $50^{\circ} \mathrm{C}, \mathrm{pH} 9,150 \mathrm{rpm}$ and $1 \mathrm{vvm}$ according to the protocol reported by Widia (2017). Samples were withdrawn every $6 \mathrm{~h}$ to monitor bacterial growth and enzyme production. Bacterial growth was expressed as colony forming unit (cfu) obtained by counting bacterial colony from the $10^{-7}$ diluted fermentation samples grown on Horikoshi agar media. Enzyme production was observed by determining volumetric and specific activity of the sample's supernatants by centrifugation of samples at $4^{\circ} \mathrm{C}, 3887 \mathrm{~g}$ by using Gyrozen 1580 centrifuge. At the end of fermentation CM1 xylanase was recovered from the supernatant of 
the culture by centrifugation at $4^{\circ} \mathrm{C}, 6000 \mathrm{rpm}(5645 \mathrm{~g})$ for 15 minutes by using Tomy Supreme 25 High Speed Refrigerated Centrifuge.

Enzyme and Protein Assays. Xylanase assays were conducted by using standardized internal laboratory protocol (IP.02-03/BKT/LAPTIAB/BPPT) that was based on xylan hydrolysis protocol reported by Bailey (1992) followed by quantification of reducing sugar by using dinitrosalicylic acid (DNS) method (Miller, 1959) with some modifications as reported by Haniyya et al. (2020). One unit of xylanase activity was defined as the amount of enzyme releasing $1 \mu \mathrm{mol}$ of reducing sugar per minute under appropriate assayed condition. Protein concentration were measured using bovine serum albumin as protein standard as reported by Bradford (1976). Xylanase activities were stated in volumetric activity $\left(\mathrm{U} \mathrm{mL}^{-1}\right)$ and specific activity $\left(\mathrm{U} \mathrm{mg}^{-1}\right)$. The latter was expressed as ratio from volumetric activity and protein concentration.

Effect of $\mathrm{pH}$ and Temperature on CM1 xylanase Activity. The effect of temperature and $\mathrm{pH}$ on the activity of CM1 xylanase were investigated in the reaction mixture containing beech wood xylan in three different buffers (50 mM): Na-phosphate (pH 7 and 8), Tris- $\mathrm{HCl}$ (pH 9 and 10), and Glycine-NaOH ( $\mathrm{pH} 11)$ at specific temperature ranging from $30-70^{\circ} \mathrm{C}$. The results were presented as specific activity.

Enzyme Stability. Stability of CM1 xylanase enzyme over a temperature range of 50 to $70^{\circ} \mathrm{C}$ were analyzed by incubating the enzyme without xylan in the optimum $\mathrm{pH}$ for 120 minutes. An aliquot of the enzyme was removed and placed on ice at 15 minutes intervals. The residual xylanolytic activity of each enzyme aliquots was determined by routine assay. Stability of CM1 xylanase enzyme toward metal ions and surfactants were studied by reacting the enzyme with $\mathrm{K}^{+}, \mathrm{Na}^{+}, \mathrm{Ca}^{2+}, \mathrm{Co}^{2+}, \mathrm{Cu}^{2+}, \mathrm{Mn}^{2+}, \mathrm{Mg}^{2+}, \mathrm{Zn}^{2+}, \mathrm{Ni}^{2+}$, $\mathrm{Fe}^{3+}$ (concentration of $1 \mathrm{mM}$ and $10 \mathrm{mM}$ ) and with Mercaptoethanol, SDS, Triton-X, Tween-80, Tween20, Teepol, and SB Chem 9201 (concentration of 0.1 and $1 \%$ ) at room temperature for one hour. Each aliquots of the enzyme was then analyzed for its residual xylanolytic activity by routine assay. The results were expressed as percentage of residual activity calculated on the basis of untreated enzyme.

Degumming of Ramie Fiber. Degumming experiments of Ramie Fiber were conducted in three different groups of degumming solution containing enzyme (A), chemical (B), and combined enzyme and chemical (C) as presented in Table 1. Degumming of ramie fiber was carried on $500 \mathrm{ml}$ Erlenmeyer flasks containing $10 \mathrm{~g}$ decorticated dried ramie fiber and 200 $\mathrm{mL}$ degumming solution. They were incubated in a reciprocal shaking incubator at $50^{\circ} \mathrm{C}, 150 \mathrm{rpm}$ for 180 minutes. Aliquots of each degumming solution at the beginning and the end of the process were analyzed for xylanolytic activities by routine assay. Degummed fiber samples were then rinsed by running water and oven dried at $50^{\circ} \mathrm{C}$. The percentage weight loss of the dried fiber samples was determined by comparing the difference between the weight of the samples before and after degumming with that of before degumming.

Characterization of Ramie Fiber. Characterization of ramie fiber was determined by measuring weight loss, tensile strength, whiteness index and surface morphology. Tensile strength was measured by SNI 08-1112-1989 using Instron Universal Testing System 3380 Series. Whiteness index was measured by SNI 08-0280-2004 using Minolta CM-3600A spectrophotometer. Surface morphology was analyzed using Scanning Electron Microscopy. Weight loss measurement was conducted in laboratory of Center for Bioindustrial Technology, BPPT while Tensile Strength and Whiteness Index were conducted at accredited laboratory of Politeknik STTT Bandung. Surface morphology observation was conducted at Cipta Mikro Material.

\section{RESULTS}

Production of CM1 xylanase. The CM1 xylanase production was conducted by submerge fermentation of $B$. halodurans CM1 with ground corncob as carbon sources in a $20 \mathrm{~L}$ bioreactor. The growth of $B$. halodurans $\mathrm{CM} 1$ and production of CM1 xylanase was observed periodically for 31 hours fermentation (Fig. 1). The culture underwent lag phase between $0-21 \mathrm{~h}$ of cultivation. The exponential growth phase occured between $21-30 \mathrm{~h}$ of cultivation and directly followed by death phase that indicated by a decreased of cell number from $2.4 \times 10^{9}$ to $1.8 \times 10^{9}$. Fig. 1a also showed that enzyme activity increases along with the increase in the number of cells and reached maximum of 641.6 $\mathrm{U} \mathrm{mL}^{-1}$ at $30 \mathrm{~h}$ in the end of exponential growth phase.

The volumetric activity of CM1 xylanase at $31 \mathrm{~h}$ of fermentation has decreased from $641.60 \mathrm{U} \mathrm{mL}^{-1}$ to 637 $\mathrm{U} \mathrm{mL}^{-1}$ then the crude enzyme was harvested by centrifugation in order to obtain the highest possible enzyme activity. Extracellular protein concentration seems to increase during the exponential growth phase between $18-27 \mathrm{~h}$ and starting to decrease between 27 - 
$31 \mathrm{~h}$. The specific activity of CM1 xylanase increase during the exponential growth phase and reached maximum activity of Fig. $1 \mathrm{c}$ showed the $475.41 \mathrm{U} \mathrm{mg}^{-1}$ at $31 \mathrm{~h}$ when the enzyme was harvested as can be seen in Fig. 1c.

Partial Characterization of CM1 xylanase. Effect of temperature and $\mathrm{pH}$ and on activity and stability of the CM1 xylanase were studied. The enzyme was active at temperature of $30^{\circ} \mathrm{C}$ to $90^{\circ} \mathrm{C}$ and pH 6 to 9. Enzyme activity increased along with the increased reaction temperature and $\mathrm{pH}$ to reach its maximum activity of $404.37 \mathrm{U} \mathrm{mg}^{-1}$ at $70^{\circ} \mathrm{C}$ and $\mathrm{pH} 9$ as can be seen in Fig. 2. When incubated at its optimum $\mathrm{pH}(\mathrm{pH}$ 9) CM1 xylanase retained more than $80 \%$ its activity in more than $120 \mathrm{~min}$ at $50^{\circ} \mathrm{C}$ and less than 30 min at $60^{\circ} \mathrm{C}$ (Fig. 3). While its activity at its optimum $\mathrm{pH}$ and temperature $\left(\mathrm{pH} 9\right.$ and $\left.70^{\circ} \mathrm{C}\right)$ seemed to be drastically dropped down to about $13 \%$ in $15 \mathrm{~min}$. Effect of metal ions and surfactants were studied. When various metal ion was mixed at room temperature for $1 \mathrm{~h}, \mathrm{~K}^{+}, \mathrm{Na}^{2+}, \mathrm{Ca}^{2+}, \mathrm{Co}^{2+}$, and $\mathrm{Cu}^{2+}$ seemed able to increase $\mathrm{CM} 1$ xylanase activity ranging from $107-130 \%$. Whereas incubation with $\mathrm{Mn} 2+$, $\mathrm{Mg} 2+, \mathrm{Zn} 2+, \mathrm{Ni} 2+$ and $\mathrm{Fe} 3+$ resulted in decreased CM1 xylanase activity ranging from $78-91 \%$ as presented in Fig. 4. When various surfactant was added at room temperature for $1 \mathrm{~h}$, Triton-X, Tween 80 , or SB-Chem 9201 at concentration of $1 \%$ seemed to increase enzyme activity ranging from $107-110 \%$. Whereas addition of SDS, Teepol, and Tween 20 at concentration $1 \%$ resulted in decrease enzyme activity ranging from $90-97 \%$ as can be seen in Fig. 5 .

Degumming of Ramie Fiber. Degumming effect of CM1 xylanase in various concentration as well as in combination with chemicals were studied on $10 \mathrm{gr}$ decorticated dried ramie fiber in a ratio of ramie : degumming solution $=1: 20$. Fig. 6 showed degumming effect as represented by weight loss seemed to increase along with the increased CM1 xylanase concentration with the highest weight loss of $7.23 \%$ reached by addition of 5\% CM1 xylanase. Chemical degumming by using $\mathrm{NaOH}(0.1 \%), \mathrm{H}_{2} \mathrm{O}_{2}$ $(1 \%)$, and their mixture showed that $\mathrm{NaOH}$ alone was able to reduce the gum content higher $(7.14 \%)$ than either $\mathrm{H}_{2} \mathrm{O}_{2}(4.76 \%)$ or in the mixture of $\mathrm{NaOH}+\mathrm{H}_{2} \mathrm{O}_{2}$ $(5.3 \%)$ as can be seen in Fig. 7. Effect of addition of surfactant (SB-Chem 9201) in enzymatic degumming was studied. It seemed addition of SB-Chem9201 resulted in slightly increased of weight loss when added with 3\% CM1 xylanase as shown in Fig. 8. Enzymatic-chemically degumming showed the weight loss of ramie fiber seemed to increase along with the increased concentration of CM1 xylanase and reached maximum weight loss of $7.7 \%$ and $6.8 \%$ at $3 \%$ and $5 \%$ CM1 xylanase in degumming solution containing $\mathrm{NaOH}$ and $\mathrm{NaOH}+\mathrm{H}_{2} \mathrm{O}_{2}$ mixture, respectively as presented in Fig. 9.

Partial Characterization of Ramie Fiber. Effect of degumming on weight loss and tensile strength of ramie fiber were compared within chemically, enzymatically, and enzymatic - chemically process. Fig. 10 showed the highest weight loss of $7.72 \%$ and $7.67 \%$ was reached by enzymatic - chemically degumming (xylanase $3 \%$ and $5 \%$, each mixed with $0.1 \% \mathrm{NaOH})$ followed by either chemically $(\mathrm{NaOH}$, $7.14 \%$ ) or enzymatically (Xylanase $3 \%, 7.15 \%$; Xylanase 5\%, 7.14\%) one. Fig. 10 also showed enzymatically degumming (xylanase $3 \%$ and $5 \%$ ) resulted in higher tensile strength of 27.5 and $26.8 \mathrm{~g} \mathrm{tex}^{-1}$ in comparison with those of chemically $(\mathrm{NaOH}, 23.7 \mathrm{~g}$ tex $^{-1}$ ) and enzymatic - chemically ( 24.7 and $24.06 \mathrm{~g} \mathrm{tex}^{-1}$ ) ones. In comparison with the control of $\mathrm{H}_{2} \mathrm{O}$-treated Rami fiber, enzymatically degummed rami fiber retained more than $90 \%$ tensile strength whereas those of chemically and enzymatic - chemically ones retained $80-83 \%$. Degumming effect on brightness showed that in the absence of xylanase, white index of rami fiber treated by $\mathrm{H}_{2} \mathrm{O}_{2}$ seemed to be higher than that of $\mathrm{NaOH}$ as shown in Fig 11. Addition of enzyme $(1-3 \%)$ resulted in an increased white index of rami fiber treated either with $\mathrm{NaOH}$ from $74.64 \%$ to $77.16 \%$ or $\mathrm{H}_{2} \mathrm{O}_{2}$ from $76.7 \%$ to $77.06 \%$. A morphological observation by electron microscope of those enzymatically and chemically degummed rami fiber revealed a slightly difference on those fiber's surfaces. As shown in Fig. 12 the surface of enzymatically degummed ramie fiber seemed smoother with less cell wall debris in comparison with those of chemical or control one.

Weight loss of ramie fiber showed the reducing of non-cellulosic impurities or gum material The result of weight loss after degumming was $4.67-7.72 \%$ presented in Figure 6. The highest weight loss of Ramie was at enzymatic + chemical degumming ( $\mathrm{S} 11=7.72$ $\%, \mathrm{~S} 8=6.49 \%$ or $\mathrm{S} 9=7.23 \%)$ compared to either enzymatic degumming ( $\mathrm{S} 2=7.15 \%$ and S3 $=7.14 \%$ ) or chemical degumming ( $\mathrm{S} 5=7.14 \%$ ). This parameter should be followed by further observation such as tensile strength, whiteness index and surface morphology.

The data on the tensile strength of Ramie fiber was stated to be homogeneous and significantly different $(\mathrm{P}$ $<0.05)$. The highest decrease in tensile strength of 

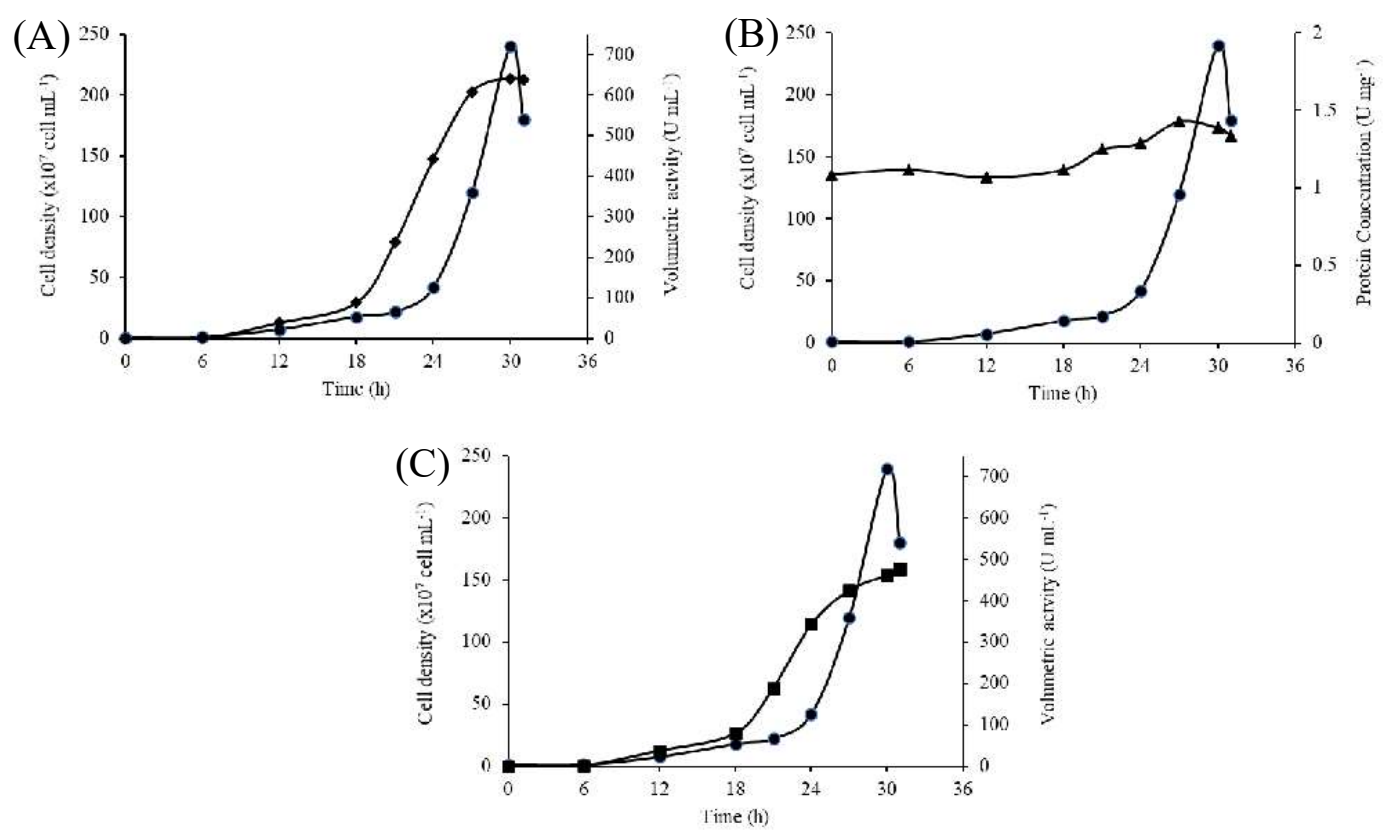

Fig 1 Curve of bacterial growth of $B$. halodurans CM1 $(\bullet)$, xylanase production based on volumetric $(\bullet)$ and specific ( $\boldsymbol{\square})$ activities, and protein production $(\boldsymbol{\Delta})$ in $15 \mathrm{~L}$ Mamo medium containing ground corncob at $50^{\circ} \mathrm{C}, \mathrm{pH} 9,1 \mathrm{vvm}$ aeration and $150 \mathrm{rpm}$ agitation. Each data point represents the average of triplicate measurements. Standard deviations are indicated by bars.

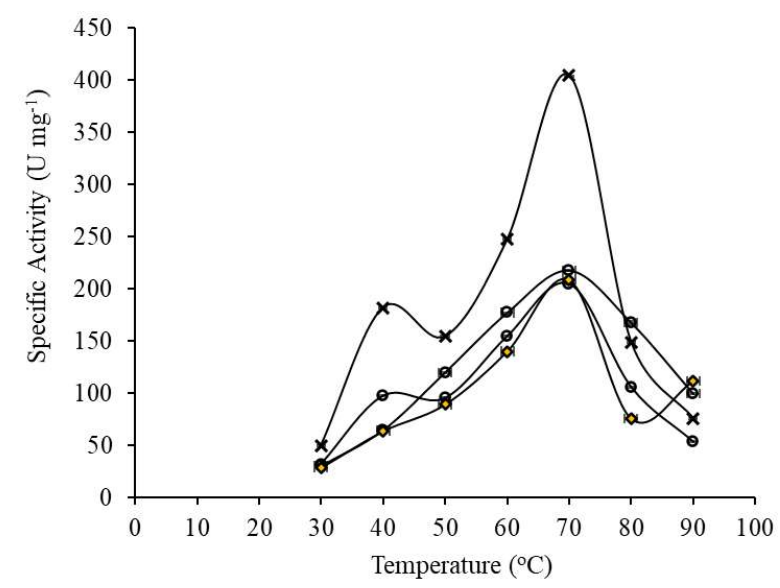

Fig 2 Effect of temperature on xylanase activity in various buffer of $\mathrm{pH} 7(\circ), \mathrm{pH} 8(\diamond), \mathrm{pH} 9(\mathrm{x}), \mathrm{pH} 10(\square)$, and $\mathrm{pH} 11(\Delta)$. Assays were conducted in triplicate. Standard deviations are indicated by bars. Absence of bars indicates that errors were smaller than symbols.

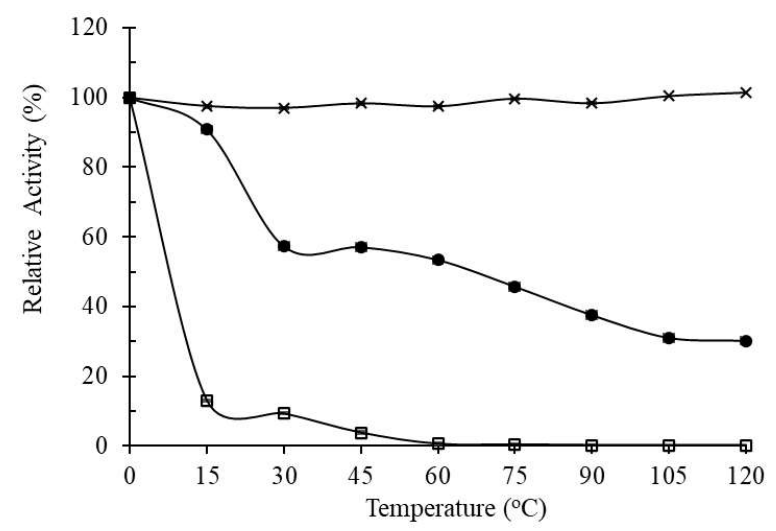

Fig 3 Thermostability of xylanase activity at optimum $\mathrm{pH} 9$ and specific temperature of $50^{\circ} \mathrm{C}(\mathrm{x}), 60^{\circ} \mathrm{C}(\bullet)$, and $70^{\circ} \mathrm{C}(\square)$ over incubation time range of 0 to $120 \mathrm{~min}$. The initial activity of $416 \mathrm{U} \mathrm{mL}^{-1}$ was defined as $100 \%$. Assays were conducted in triplicate. Standard deviations are indicated by bars. Absence of bars indicates that errors were smaller than symbols. 


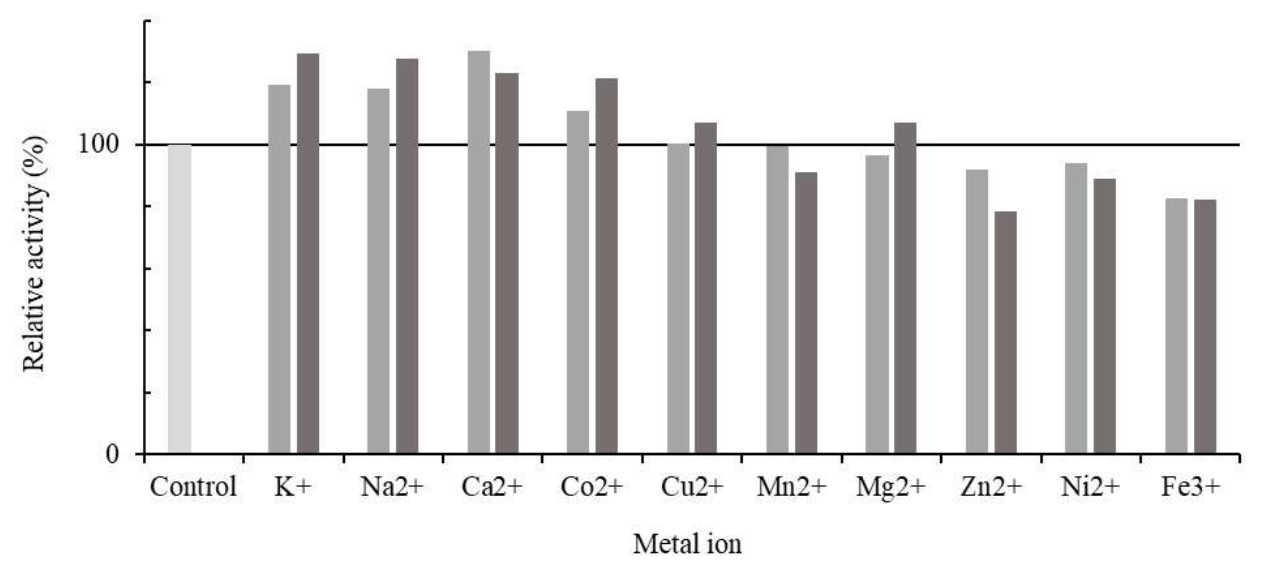

Fig 4 Effect of metal ions on xylanase activity. The enzyme was incubated at room temperature with $1.0 \mathrm{mM}(\square)$ and $10.0 \mathrm{mM}(\square)$ concentrations of metal ions without substrate for $1 \mathrm{~h}$ prior subjected to routine xylanase assay. A control of untreated enzyme ( $\square$ ) was $416 \mathrm{U} \mathrm{mL}^{-1}$ and defined as $100 \%$. Assays were conducted in triplicate.

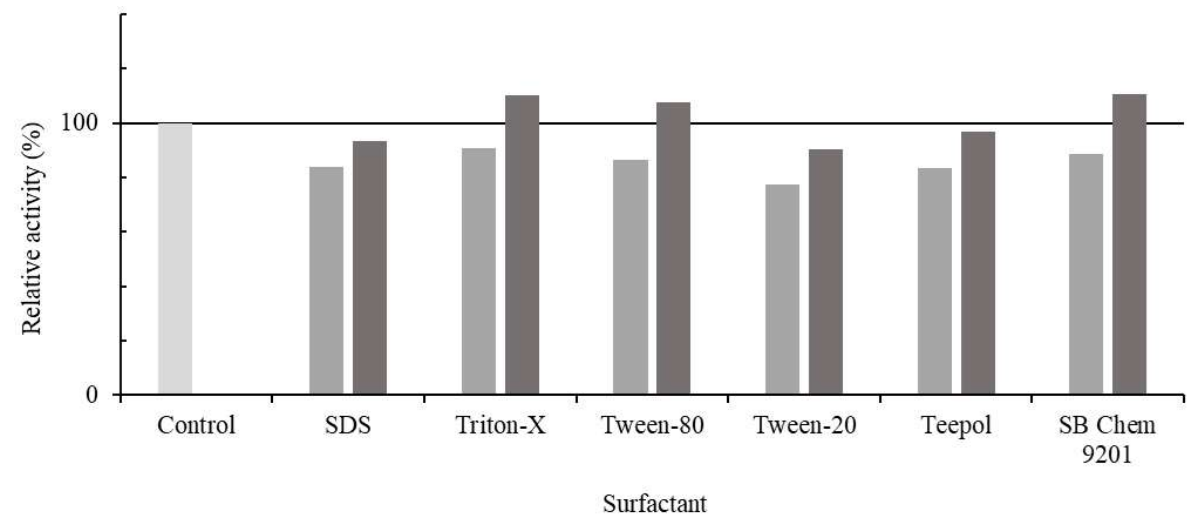

Fig 5 Effect of surfactants on xylanase activity. The enzyme was incubated at room temperature with $0.1 \%(\square)$ and $1 \%$ ( $\square$ ) concentrations of surfactants without substrate for $1 \mathrm{~h}$ prior subjected to routine xylanase assay. A control of untreated enzyme ( $\square$ ) was $416 \mathrm{U} \mathrm{mL}^{-1}$ and defined as $100 \%$ activity. Assays were conducted in triplicate. Standard deviations are indicated by bars.

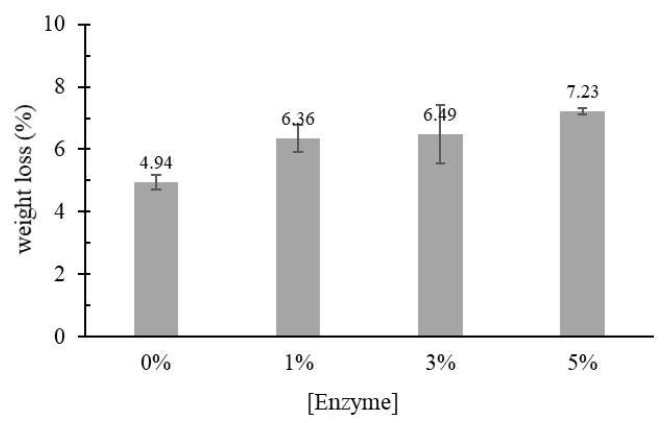

Fig 6 Enzymatic degumming effect on weight loss of ramie fiber with xylanase concentration range of 0 to $5 \%$ at $50^{\circ} \mathrm{C}, 150 \mathrm{rpm}$ for $3 \mathrm{~h}$. Experiments were conducted in triplicate. Standard deviations are indicated by bars.

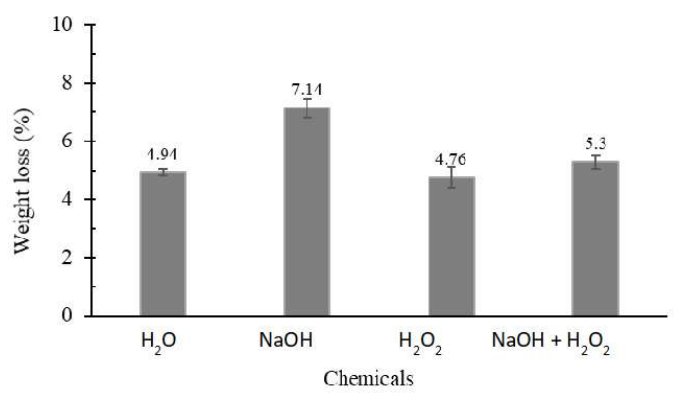

Fig 7 Chemical degumming effect on weight loss of ramie fiber with various chemicals $\mathrm{NaOH}(0.1 \%), \mathrm{H}_{2} \mathrm{O}_{2}$ $\left(1 \%\right.$, ) and a mixture of $\mathrm{NaOH}+\mathrm{H}_{2} \mathrm{O}_{2}$ at $50^{\circ} \mathrm{C}, 150 \mathrm{rpm}$ for $3 \mathrm{~h}$. Experiments were conducted in triplicate. Standard deviations are indicated by bars. 


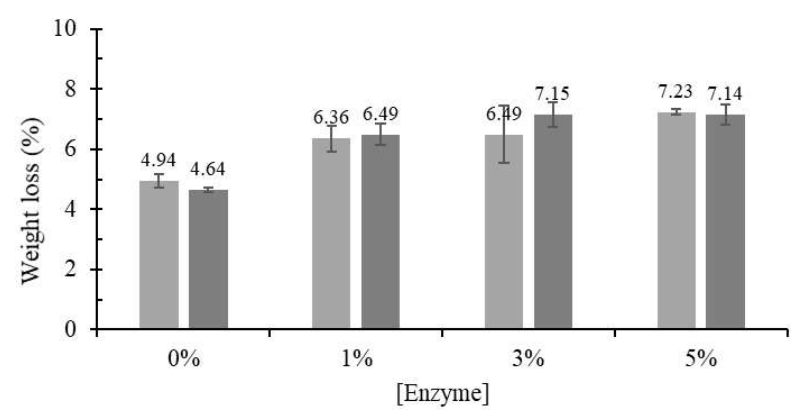

Fig 8 Enzymatic degumming effect on weight loss of ramie fiber in solution containing xylanase (concentration range of 0 to $5 \%$ ) with ( $\square$ ) and without ( $\square$ ) addition of surfactant (SB Chem 9201) at $50^{\circ} \mathrm{C}, 150 \mathrm{rpm}$ for $3 \mathrm{~h}$. Experiments were conducted in triplicate. Standard deviations are indicated by bars.

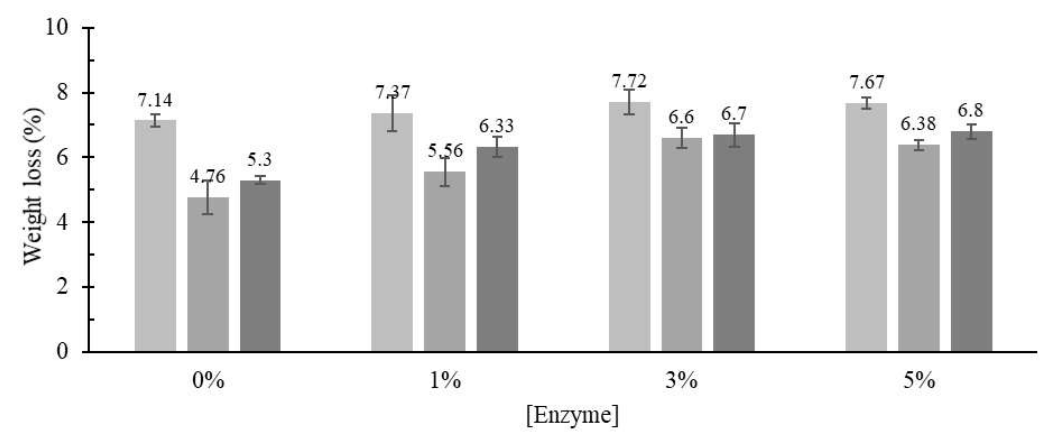

Fig 9 Chemical-enzymatically degumming effect on weight loss of ramie fiber in solution containing xylanase (concentration range of 0 to $5 \%$ ) with $0.1 \% \mathrm{NaOH}(\square), 1 \% \mathrm{H}_{2} \mathrm{O}_{2},(\square)$ and a mixture of $\mathrm{NaOH}+\mathrm{H}_{2} \mathrm{O}_{2}(\square)$ at $50^{\circ} \mathrm{C}, 150 \mathrm{rpm}$ for $3 \mathrm{~h}$. Experiments were conducted in triplicate. Standard deviations are indicated by bars.

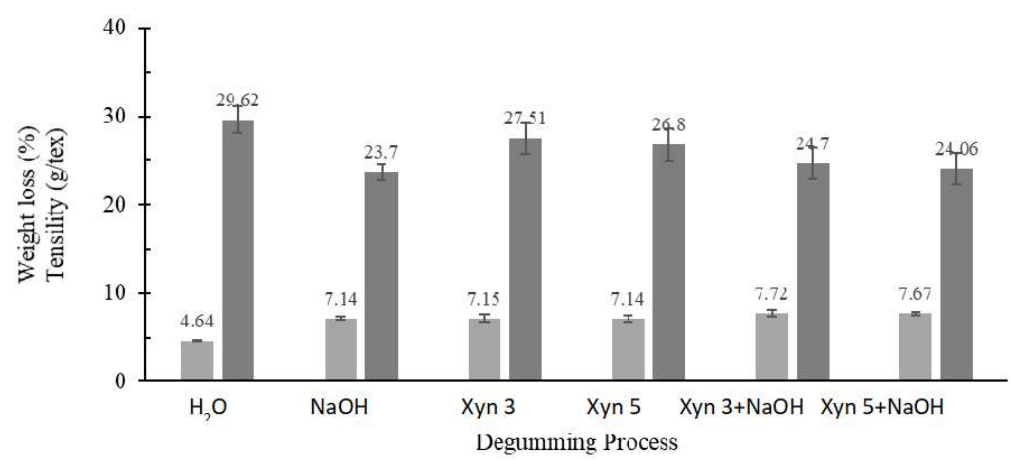

Fig 10 Effect of various degumming process on Weight loss ( $\square$ ) and Tensil Strength ( $\square$ ) of ramie fiber. The process was conducted as control (H2O), chemically $(\mathrm{NaOH})$, enzymatically (Xyn 3 and Xyn 5), and chemicalenzymatically (Xyn3+NaOH and $\mathrm{Xyn} 5+\mathrm{NaOH}$ ) degumming. Experiments and measurements were conducted in triplicate. Standard deviations are indicated by bars.

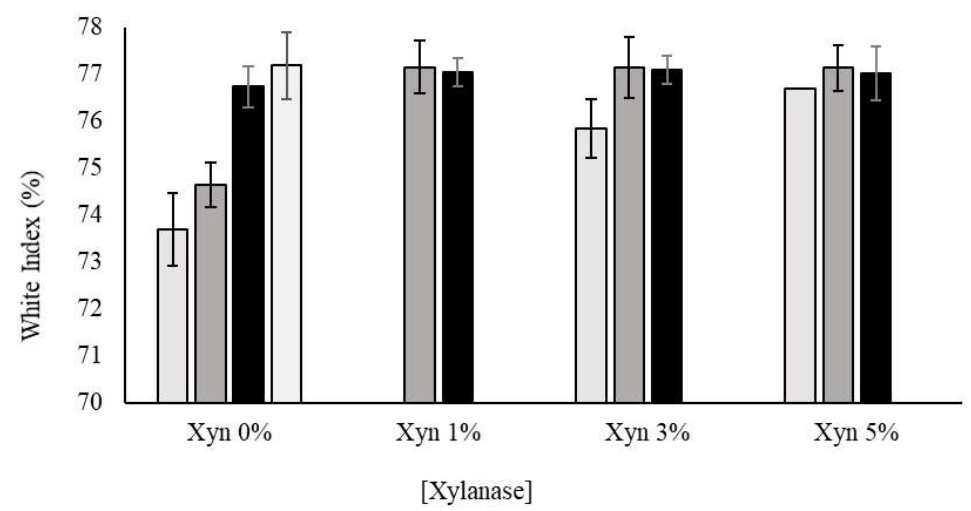

Fig 11 Effect of various concentration of enzyme on White index in degumming solution contining $\mathrm{NaOH}(\square), \mathrm{H}_{2} \mathrm{O}_{2}$ $(\square)$, a mixture of $\mathrm{NaOH}+\mathrm{H}_{2} \mathrm{O}_{2}(\mathrm{)})$, and a control $\mathrm{H}_{2} \mathrm{O}(\square)$. Experiments and measurements were conducted in triplicate. Standard deviations are indicated by bars. 


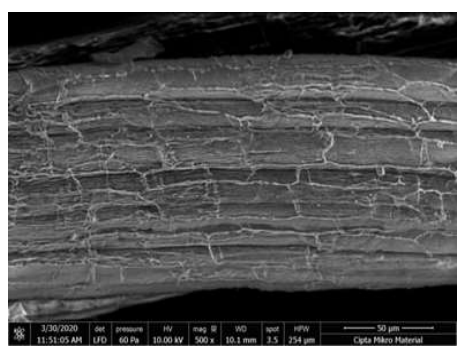

A

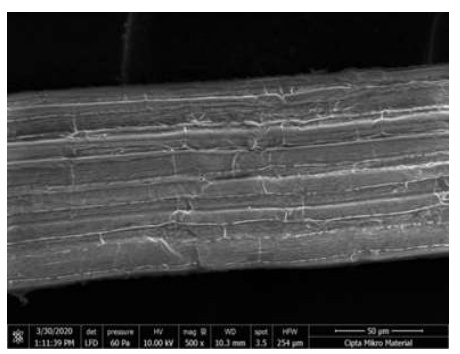

B

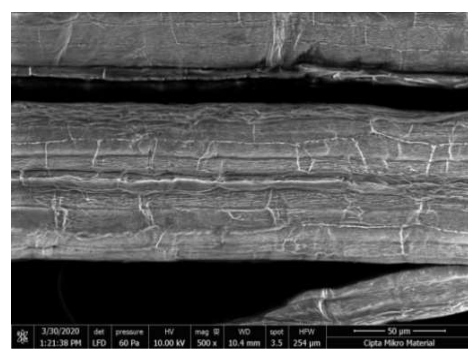

$\mathrm{C}$

Fig 12 Surface morphology (SEM) of Ramie fibers. Control (untreated) (A); Xylanase 3\% (B); NaOH 0.1\% (C).

ramie fiber was on chemical degumming ( $\mathrm{S} 19=21.24$ $\mathrm{g} /$ tex and S5 $23.7 \mathrm{~g} /$ tex) compared to control (29.62 $\mathrm{g} / \mathrm{tex}$. The tensile strength of Ramie fiber relatively maintained by enzymatic degumming $(\mathrm{S} 2=27.51$ $\mathrm{g} /$ tex and $\mathrm{S} 3=26.8 \mathrm{~g} /$ tex) which better than chemical degumming (Fig 7).

The result of whiteness indexwas quite significant compared to unbleached ramie fiber. The highest whiteness index obtained by chemical degumming $(\mathrm{S} 19=77.19 \%)$ while enzymatic degumming also showed significant effect $(\mathrm{S} 2=75.85 \%$ and $\mathrm{S} 3=76.69$ $\%$ ) compared to control ( $\mathrm{K}=73.70 \%$ ) (Fig 8).

The results of the Ramie fiber morphology test using SEM (Scanning Electron Microscopy)where enzymatic degumming by using xylanase (B) showed that the gummy material of the surface was smoother than decorticated fiber used as control (A) and chemical treatment by using $\mathrm{NaOH}$ (C) (Fig 9).

\section{DISCUSSION}

Xylanases have attracted a great deal of attention in the last decade particularly due to their eco-friendly application in various manufacture industries such as pulp and paper, biofuel, and textile. In this study CM1 xylanase production was conducted in a stirred tank 20 L bioreactor in which aeration, agitation, $\mathrm{pH}$ and heat transfer were able to be controlled to facilitate optimum cultivation condition. As presented above CM1 xylanase was produced by $B$. halodurans CM1 during the exponential phase following a relatively long lag phase of almost $20 \mathrm{~h}$. It is suggested that the presence of ground corncob and mechanical agitation in the bioreactor resulted in a relatively significance change between shake flask and bioreactor environment that induced cellular stress (Hallsworth 2018). Thus, the bacterial cells required more extensive period of adjustment before starting to grow and in consequence lengthen the lag phase. Moreover, ground corncob as carbon source could not be directly used by the bacterial cell. It explained the exponential cell growth that not started until the increased CM1 xylanase activity between $18-30 \mathrm{~h}$ cultivation. The enzyme obtained by using bioreactor in this study was $637.7 \mathrm{U} \mathrm{mL}^{-1}$ or $475.41 \mathrm{U} \mathrm{mg}^{-1}$ after $31 \mathrm{~h}$ cultivation. This result was relatively higher than that of gained by using shake flask that reached maximum activity of $522 \mathrm{U} \mathrm{mL}^{-1}$ (Wibowo et al.2016). Similarly, Ling Ho (2016) reported that xylanase production by Bacillus subtilis in bioreactor yielded much higher activity than that of in shake flask.

The activity of CM1 xylanase towards beechwood xylan in various $\mathrm{pH}$ and temperature showed that the enzyme was optimally active at $\mathrm{pH} 9$ and $70^{\circ} \mathrm{C}$. This optimum $\mathrm{pH}$ and temperature were similar with that of thermostable alkaline xylanase from Anoxybacillus kamchatkensis reported by Yadav et al (2018). The thermal stability of the enzyme indicated that the CM1 xylanase was fully stable after $2 \mathrm{~h}$ incubation at $50^{\circ} \mathrm{C}$. However, its stability that represented by residual activity, seemed to decrease down to less than $60 \%$ and $30 \%$ when the enzyme was incubated for $30 \mathrm{~min}$ at elevated temperature of 60 and $70^{\circ} \mathrm{C}$, respectively. It is suggested that the enzyme was denatured after $30 \mathrm{~min}$ incubation at $60^{\circ} \mathrm{C}$. This result was lower than that of Mamo et al (2006) who demonstrated that the xylanase from $B$. halodurans $\mathrm{S} 7$ retained over $60 \%$ residual activity after $3 \mathrm{~h}$ incubation at $65^{\circ} \mathrm{C}$. Differences in the result presumably due to differences in the origin of the bacterial isolates and the purity of the enzyme. $B$. halodurans CM1 was isolated from Indonesian Cimanggu hot spring (Ulfah et al.2011) while that of S7 strain was isolated from Ethiopian Soda Lake (Mamo et al. 2006). In this study we used crude xylanase enzyme instead of partially purified one used by Mamo et al (2006). The activity of the CM1 xylanase toward metal ions indicated that the enzyme was inhibited by $\mathrm{Fe}^{2+}$ and $\mathrm{Zn}^{2+}$ and activated by $\mathrm{Na}^{2+}$ and $\mathrm{Ca}^{2+}$. Metal ions binds with enzyme catalytic site which enhance the interaction of enzyme with substrate 
(Anand et al.2013). In industrial process, metal ions might be contained in water or other reagents used for its process, which will affect enzyme activity (Pereira et al.2017). Meanwhile the enzyme activity was slightly inhibited by almost all tested surfactants except Triton X, Tween 80 and SB-Chem 9210. Nonionic surfactants have been used as wetting agent to increase water absorption in textile processing. The use of $1.25 \%$ Tween-20 enhanced the effectivity of enzymatic degumming process (Singh et al.2019). The information of enzyme activator and inhibitor was relevant in this study, in which the enzyme would be applied in degumming process of ramie fiber that was adapted to the existing method used by local small scale ramie fiber producer. The enzyme was used for degumming of ramie fiber under the designed condition considering the enzyme stability towards $\mathrm{pH}$ and temperature. In this study degumming effect of CM1 xylanase, alone as well as in combination with chemical $(\mathrm{NaOH})$, was observed and compared with that of chemical one. Degumming effect was observed by determining weight loss of ramie fiber, that represented the reducing of non-cellulosic impurities or gum material. This study revealed the highest weight loss of ramie was reached by chemical - enzymatically degumming proses, in which $0.1 \% \mathrm{NaOH}$ was added with either $3 \%$ or $5 \%$ CM1 xylanase. This result indicates a synergistic action of $\mathrm{NaOH}$ in degrading gum material. Addition of $\mathrm{NaOH}$ created an alkali milieu of degumming solution by which gum material partially degrade (Cheng et al.2020) at the same time $\mathrm{Na}^{2+}$ acted as activator CM1 xylanase enhanced hemicellulose breakdown. Beside metal ion of $\mathrm{Na}^{2+}$, the addition of surfactant (SB-Chem 9201) showed to enhance degradation of gum material. This is in accordance with that of Singh et al. (2019) who reported the addition of $1 \%$ surfactant, as a wetting agent, increases the absorbance capacity of the fibers so that the enzyme penetration in the fiber pores is better. In this study effect of $\mathrm{H}_{2} \mathrm{O}_{2}$ on degumming was also observed. Hydrogen peroxide is usually used as bleaching agent. The result showed an opposed action of $\mathrm{H}_{2} \mathrm{O}_{2 \text { that }}$ resulted in decreased weight loss when added with either $\mathrm{NaOH}$ or $\mathrm{CM} 1$ xylanase in the degumming solution. Degumming process, either enzymatically or chemically, reduces tensile strength of ramie fiber caused by the removal of non-cellulosic impurities by which reducing its stiffness. Therefore, tensile strength analyses of ramie fiber was conducted and revealed that enzymatically degummed ramie fiber retained the higher tensile strength compared to chemically degummed. It is similar to the research of where enzymatic treatment showed tensile strength of 7.19 $\mathrm{cN} / \mathrm{dtex}$ higher than alkali degumming of $6 \mathrm{cN} / \mathrm{dtex}$. It is suggested that addition of chemicals $(\mathrm{NaOH}$ and $\mathrm{H}_{2} \mathrm{O}_{2}$ ) led to damage not only to non-cellulosic impurities but also to cellulosic fiber. Degumming effect on brightness was studied and showed that $\mathrm{H}_{2} \mathrm{O}_{2}$ was a stronger bleaching agent in comparison to $\mathrm{NaOH}$. However, addition of CM1 xylanase in combination with $\mathrm{NaOH}$ was able to significantly increase white index. This in accordance with bleaching boost effect of the xylanase of $B$. halodurans C-125 in previous study by Lin et al. (2013), who demonstrated that the addition of the $\mathrm{C}-125$ xylanase was able to reduce $10 \%$ chlorine as bleaching agent in wheat straw pulp bleaching. Fiber surface analyses showed that enzymatically degumming ramie fiber was relatively smoother in comparison with that of the chemically one. Enzymatic degumming enhances the separation of non-cellulosic with cellulosic components that makes fiber surface was smoother (Rani et al.2019). In conclusion, CM1 xylanase either alone or in combination with $\mathrm{NaOH}$ was a better degumming solution in comparison to that of the chemical one. Enzymatic degumming produced ramie fiber that relatively preserve the tensile strength and smoother surface. Aiming to obtain more effective enzymatic degumming, it is necessary to conduct further study on application of pectinase in combination with CM1 xylanase.

\section{ACKNOWLEDGEMENTS}

Authors thank for the support of Master Program of Biotechnology, Institut Teknologi Bandung and the Centre for Bioindustrial Technology, the Agency for the Assessment and Application of Technology. This research work has been funded by Beasiswa Saintek from The Ministry of Research and Technology of the Republic of Indonesia and supported in part by the LPDP - Research Grant (Project No. 171/E1/PRN/2020) in cooperation with The Ministry of Research and Technology of the Republic of Indonesia/BRIN.

\section{REFERENCES}

Abd El Aty AA, Saleh SAA, Eid BM, Ibrahim NA, Mostafa FA. 2018. Thermodynamics characterization and potential textile applications of Trichoderma longibrachiatum KT693225 xylanase. Biocatal Agric 
Biotechnol 14:129-137. doi: 10.1016/j.bcab.2018. 02.011 .

Anand A, Kumar V, Satyanarayana T. 2013. Characteristics of thermostable endoxylanase and $\beta$-xylosidase of the extremely thermophilic bacterium Geobacillus thermodenitrificans TSAA1 and its applicability in generating xylooligosaccharides and xylose from agroresidues. Extremophiles 17:357-366. doi: 10.1007/s00792-013-0524-x.

Atalah J, Cáceres-moreno P, Espina G, Blamey JM. 2019. Thermophiles and the applications of their enzymes as new biocatalysts. Bioresour Technol. 280:478-488. doi: 10.1016/j.biortech.2019.02.008.

Bailey MJ. 1992. Interlaboratory testing of methods for assay of xylanase activity. J. Biotechnol. 23, 257-270.

Battan B, Dhiman SS, Ahlawat S, Mahajan R, Sharma J. 2012. Application of thermostable xylanase of Bacillus pumilus in textile processing. Indian $\mathrm{J}$ Microbiol 52:222-229. doi: 10.1007/s12088-011-0118-1.

Bibi Z, Asif M, Waqas M, Aman A. 2018. Significance of metal ions, solvents and surfactants to improve the xylan degrading behavior of $\beta$-1, 4-D-xylanohydrolase from Geobacillus stearothermophilus KIBGE-IB29 Biocat Agricult Biotechnol. doi: 10.1016/j.bcab.2018.11.028.

Chiliveri SR, Koti S, Linga VR. 2016. Retting and degumming of natural fibers by pectinolytic enzymes produced from Bacillus tequilensis SV11 - UV37 using solid state fermentation. Springerplus. doi: 10.1186/s40064-016-2173-x.

Ding RY, Zhang XQ, Yu CW. 2014. Optimization of enzyme mixture degumming of Ramie fiber. J Nat Fibers 11:13-24. doi: 10.1080/15440478.2013.824851.

Gaur R, Tiwari S, Rai P, Srivastava V. 2015. Isolation, production, and characterization of thermotolerant xylanase from solvent tolerant Bacillus vallismortis RSPP-15. Int J Polym Sci 2015. doi: $10.1155 / 2015 / 986324$.

Heux S, Meynial-Salles I, O'Donohue MJ, Dumon C. 2015. White biotechnology: State of the art strategies for the development of biocatalysts for biorefining. Biotechnol Adv 33:1653-1670. doi: 10.1016/j.biotechadv.2015.08.004.

Irdawati, Syamsuardi, Agustien A, Rilda Y. 2016. Xylanase enzyme stability and biochemical characteristics thermoxylanolytic bacteria from mudiak sapan hot springs at Solok Selatan district. Der Pharm Lett 8:254-261.

Jiang W, Song Y, Liu S, Ben H, Zhang Y, Zhou C, Han G, Ragauskas AJ. 2018. A green degumming process of ramie. Ind Crops Prod 120:131-134. doi: 10.1016/j.indcrop.2018.04.045.

Kumar D, Kumar SS, Kumar J, Kumar O, Mishra SV, Kumar R, Malyan SK. 2017. Xylanases and their industrial applications: A review. Biochem Cell Arch
17:353-360. doi: 10.1007/s002530100704.

Kumar S, Haq I, Prakash J, Kumar S. 2017. Purification, characterization and thermostability improvement of xylanase from Bacillus amyloliquefaciens and its application in pre-bleaching of kraft pulp. 3 Biotech 7:1-12. doi: 10.1007/s13205-017-0615-y.

Kumar V, Satyanarayana T. 2011. Applicability of thermoalkali-stable and cellulase-free xylanase from a novel thermo-halo-alkaliphilic Bacillus halodurans in producing xylooligosaccharides. Biotechnol Lett 33:2279-2285. doi: 10.1007/s10529-011-0698-1.

Lee C, Khalina A, Lee S, Liu M. 2019. A Comprehensive Review on Bast Fiber Retting Process for Optimal Performance in Fibers Reinforced Polymer Composites. Preprints 2019110310:1-40.

Ling Ho H. 2016. Batch submerged fermentation in shake flask culture and bioreactor: Influence of different agricultural residuals as the substrate on the optimization of Xylanase Production by Bacillus subtilis and Aspergillus brasiliensis. J Appl Biotechnol Bioeng 1. doi: 10.15406/jabb.2016.01.00016.

Mamo G, Hatti-Kaul R, Mattiasson B. 2006. A thermostable alkaline active endo- $\beta$-1-4-xylanase from Bacillus halodurans S7: Purification and characterization. Enzyme Microb Technol 39:1492-1498. doi: 10.1016/j.enzmictec.2006.03.040.

Mishra L, Das R, Mustafa I, Basu G, Gogoi N. 2019. A Novel approach of low alkali degumming of Ramie. J Nat Fibers 00:1-10. doi: 10.1080/15440478.2019.1658257.

Mohammad BT, Al Daghistani HI, Jaouani A, Abdel-Latif S, Kennes C. 2017. Isolation and characterization of thermophilic bacteria from Jordanian hot springs: Bacillus licheniformis and Thermomonas hydrothermalis isolates as potential producers of thermostable enzymes. Int J Microbiol 2017. doi: $10.1155 / 2017 / 6943952$.

Mukhopadhyay A, Dutta N, Chattopadhyay D, Chakrabarti K. 2013. Degumming of ramie fiber and the production of reducing sugars from waste peels using nanoparticle supplemented pectate lyase. Bioresour Technol 137:202-208. doi: 10.1016/j.biortech.2013.03.139.

Novarini E, Sukardan MD. 2015. the Potency of ramie fiber (Boehmeria nivea $\mathrm{S}$. Gaud) technical textile industries. Arena Tekstil 30:113-122

Pereira J de C, Giese EC, Moretti MM de S, Gomes AC dos S, Perrone OM, Boscolo M, da Silva R, Gomes E, Martins DAB. 2017. Effect of metal ions, chemical agents and organic compounds on lignocellulolytic enzymes activities. Enzym Inhib Act. doi: $10.5772 / 65934$.

Rani K, Ahirwar M, Behera BK. 2020. Comparative analysis of alkaline and enzymatic degumming process of hemp fibers. J Inst Eng Ser E 101. doi: 10.1007/s40034-01900156-y. 
Ray DP, Satya P, Mitra S, Banerjee P, Ghosh RK. 2014. Degumming of ramie: Challenge to the queen of fibres. 1:37-41.

Singh A, Varghese LM, Battan B, Patra AK, Mandhan RP, Mahajan R. 2019. Eco-friendly scouring of ramie fibers using crude xylano-pectinolytic enzymes for textile purpose.

Ulfah M, Helianti I, Wahyuntari B, Nurhayati N. 2011. Characterization of a new thermoalkalophilic xylanaseproducing bacterial strain isolated from Cimanggu Hot Spring, West Java, Indonesia. Microbiol Indones
5:139-143. doi: 10.5454/mi.5.3.7.

Wibowo SG, Helianti I, Suryani A, Wahyuntari B. 2016. Application of response surface method in optimization of medium composition for xylanase production by Bacillus halodurans CM1 in submerged fermentation. Microbiol Indones 10:112-117. doi: 10.5454/mi.10.3.5.

Zhou C, Xue Y, Ma Y. 2017. Characterization and overproduction of a thermo-alkaline pectate lyase from alkaliphilic Bacillus licheniformis with potential in ramie degumming. 54:49-58. 